\title{
Coal Technology Program Progress Report for November 1976
}




\section{DISCLAIMER}

This report was prepared as an account of work sponsored by an agency of the United States Government. Neither the United States Government nor any agency Thereof, nor any of their employees, makes any warranty, express or implied, or assumes any legal liability or responsibility for the accuracy, completeness, or usefulness of any information, apparatus, product, or process disclosed, or represents that its use would not infringe privately owned rights. Reference herein to any specific commercial product, process, or service by trade name, trademark, manufacturer, or otherwise does not necessarily constitute or imply its endorsement, recommendation, or favoring by the United States Government or any agency thereof. The views and opinions of authors expressed herein do not necessarily state or reflect those of the United States Government or any agency thereof. 


\section{DISCLAIMER}

Portions of this document may be illegible in electronic image products. Images are produced from the best available original document. 


\section{Printed in the United States of America. Available from National Technical Information Service \\ U.S. Department of Commerce 5285 Port Royal Road, Springfield, Virginia 22161 \\ Price: Printed Copy $\$ 4.00$; Microfiche $\$ 3.00$}

This report was prepared as an account of work sponsored by the United States Government. Neither the United States nor the Energy Research and Development Administration/United States Nuclear Regulatory Commission, nor any of their employees. nor any of their contractors, subcontractors, or their employees, makes any warranty, express or implied, or assumes any legal liability or responsibility for the accuracy, completeness or usefulness of any information, apparatus, product or process disclosed, or represents that its use would not infringe privately owned rights. 
Contract No. $w-740 \not 2-e n g-26$

COAL TECHNOLOGY PROGRAM

PROGRESS REPORT FOR NOVEMBER 1976

Date Published: January 1977

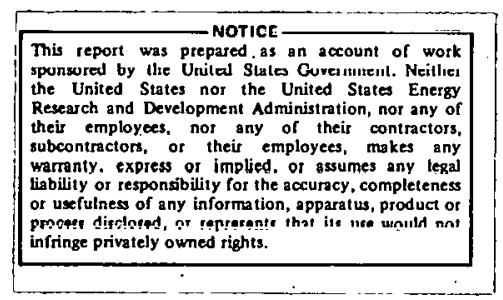

NOTICE This document contains information of a preliminary nature. It is subject to revision or correction and therefore does not represent a final report.

\author{
OAK RIDGE NATIONAL LABORATORY \\ Oak Ridge, Tennessee 37830 \\ operated by \\ UNION CARBIDE CORPORATION \\ for the \\ ENERGY RESEARCH AND DEVELOPMENT ADMINISTRATION
}




\title{
PREVIOUS REPORTS IN THIS SERIES
}

\author{
ORNL/TM-5044, Progress Report for August 1974 \\ ORNL/TM-5045, Progress Report for September 1974 \\ ORNL/TM-5046, Progress Report for October 1974 \\ ORNL/TM-4787, Progress Report for November 1974 \\ ORNL/TM-4796, Progress Report for December 1974 \\ ORNL/TM-4850, Progress Report for January 1975 \\ ORNL/TM-4873, Progress Report for February 1975 \\ ORNL/TM-4892, Progress Report for March 1975 \\ URNL/IM-4946, Progress Report for April 1975 \\ ORNL/TM-4966, Progress Report for May 1975 \\ ORNL/TM-5010, Progress Report for June 1.97 .5 \\ ORNL/TM-5037, Progress Report for July 1975 \\ ORNL/TM-5092, Progress Report for August 1975 \\ ORNL/TM-5124, Progress Report for September 1975 \\ ORNL/TM-5186, Progress Report for October 1975 \\ ORNL/TM-5214, Progress Report for November 1975 \\ ORNL/TM-5246, Progress Report for December 1975 \\ ORNL/TM-5301, Progress Report for January 1976 \\ ORNL/TM-5321, Progress Report for February 1976 \\ ORNL/TM-5430, Progress Report for March 1976 \\ ORNL/TM-5479, Progress Report for April 1976 \\ ORNL/TM-5532, Progress Report for May 1976 \\ ORNL/TM-5595, Progress Report for June 1976 \\ ORNL/TM-5611, Progress Report for July 1976 \\ ORNL/TM-5654, Progress Report for August 1976 \\ ORNL/TM-5674, Progress Report for September 1976 \\ ORNL/TM-5717, Progress Report for October 1976
}


CONTENTS

$\underline{\text { Page }}$

Abstract . . . . . . . . . . . . . . . . . . . . . . . 1

1. Summary . . . . . . . . . . . . . . . . . . . . . 1

2. Coal Conversion Process Development . . . . . . . . . . . . 4

2.1 Hydrocarbonization Research . . . . . . . . . . . . . 4

2.2 Residue Carbonization . . . . . . . . . . . . . . 4

2.3 Experimental Engineering Support of an In Situ Gasification Process . . . . . . . . . . . 6

2.4 Coal-Solvent-Hydrogen Mixing . . . . . . . . . . . 7

2.5 Pressurized Carbonization of Consol Synthetic Fuel Solid Residues . . . . . . . . . . . . 8

3. Mațerials Engineering . . . . . . . . . . . . . . . . 10

3.1 Pressure Vessel and Piping Technology Assessment . . . . . 11

3.2 Inspection Techniques for Wear- and Process-Resistant Coatings . . . . . . . . . . . . . . . . 11

3. 3 Iron and Nickel Carbonyl Formation and Prevention . . . . . 13

3.4 Failure Prevention and Analysis . . . . . . . . . . . . 13

3.5 Prestressed Concrete Pressure Vessel Studies . . . . . . . 14

3.6 Cladding with Alloy 20 . . . . . . . . . . . . . 15

3.7 Fluidized Bed Combustion . . . . . . . . . . . 15

4. Alkali Metal Vapor Topping Cycles . . . . . . . . . . . 16

4.1 Potassium Vapor Cycle . . . . . . . . . . . . . 16

4.2 Coal-Fired Alkali Metal . . . . . . . . . . . . . 18

5. Critical Components Test Facility . . . . . . . . . . . . . . 19

6. Engineering Studies and Technical Support . . . . . . . . . . . 20

6.1 Process Modeling Support . . . . . . . . . . . . . 20

6.2 Process Research Digest . . . . . . . . . . . . . . . 21

6.3 Survey of Industrial Equipment Capabilities . . . . . . . . 21

6.4 Large Air Separation Plant Study . . . . . . . . . . . . 22 
7. Process and Program Assistance... . . . . . . . . . . 23

7.1 Low-Btu Coal Gasification . . . . . . . . . . . . . 23

7.2 Direct Combustion . . . . . . . . . . . . . . 23

7:3 Advanced Power Conversion Systems . . . . . . . . . . . . 24

7.4 Liquefaction and High-Btu Gas . . . . . . . . . . . . . . 25

7.5 In Situ Coal Gasification. . . . . . . . . . . . . 25

7.6 Bcncficiation . . . . . . . . . . . . . . . . 26

7.7 Gas Cleanup . . . . . . . . . . . . . . . . . 26

1.8 Coal frices and Volumes . . . . . . . . . . . . . 27

7.9 Energy Transportation Costs . . . . . . . . . . . 27

8. Fossil Energy Environmental Project . . . . . . . . . . 28

9. Coal-Fueled MIUS . . . . . . . . . . . . . . . . . 29

9.1 Program Review Status . . . . . . . . . . . . . . 29

9.2 Coal Metering and Feed Systems . . . . . . . . . . . . 29

9.3 Supplemental Studies . . . . . . . . . . . . . . 29

10. Analytical Chemistry . . . . . . . . . . . . . . . 30

10.1 Sephadex Class Separations . . . . . . . . . . 30

11. Chemical Research (reported quarterly)

12. Life Sciences (reported quarterly) 
COAL TECHNOLOGY PROGRAM PROGRESS REPORT FOR NOVEMBER 1976

\section{ABSTRACT}

This report - the twenty-eighth of a series - is a compendium of monthly progress reports for the ORNL research and development programs that are in support of the increased utilization of coal as a source of clean energy. The projects reported this month include those for coal conversion process development, materials engineering, alkali metal vapor topping cycles, a Critical Components Test Facility, engineering and support studies, environmental assessment studies, and coal-fueled MIUS.

\section{SUMMARY}

J. P. Nichols

The following are highlights of our progress in November:

- Operations of the 20-atm, bench-scale hydrocarbonization facility continued with the successful completion of Run HC-9. The reactor was operated as a recirculating fluidized-bed at 300 psig $\mathrm{H}_{2}$ pressure and $950^{\circ} \mathrm{F}$ with Wyodak subbituminous coal as feed.

- Three residue carbonization experiments were made - Runs RC-17, $\mathrm{RC}-18$, and $\mathrm{R}-19$ - with a $4 / 1$ ratio of char to $\mathrm{H}-\mathrm{Coal}$ vacuum distillation residue as feed. Persistent plugging problems in the reactor effluent line, and occasionally in the feed line, continue to frustrate attempts to sustain operation at steady state for completion of material balances.

- Simulated contactor studies are continuing in our coal-solventhydrogen mixing project. A coal-water slurry containing $37 \mathrm{wt} \%$ coal was added to the 55-gal surge tank in the slurry circulation loop. Tests were run which showed that: (1) at a slurry flow rate of $\sim 4$ gal per min, the flowing stream had the same coal concentration as the agitated surge tank, and (2) the slurry pump does not change the size distribution of the coal particles. The technique for measuring dispersion in the reactors by injecting pulses of $\mathrm{KCl}$ tracer must be refined to eliminate errors.

- Fluor Engineers and Constructors is designing a plant using the Consol Synthetic Fuel Process in which they wish to consider low temperature $\left(\sim 900^{\circ} \mathrm{F}\right)$ carbonization of a mixture of hydroclone underflow and a recycle oil at 50 and 400 psig. ORNL has been asked to quickly provide estimates of how much oil is thermally degraded. An experiment has been proposed to provide this information, equipment has been designed, and some items have been procured. 
- A draft of the report, $\Lambda$ ssessment of Materials Technology of Pressure Vessel and Piping for Coal Conversion (ORNL-5238), has been completed as the first phase of our project for assessment of piping and pressure vessels. Procurement of several pressure vessel steels for heat treatment and characterization studies was completed.

- Several activities for inspection of wear- and process-resistant coatings are being pursued. We have contacted Argonne National Laboratory for a direct update on coating selection work. We have contacted Coating Systems Technology to discuss duplication of ANL specimens and have requested ANL to release technical data relative to these specimens. Purchasing activities for our $x$-ray fluorescence system are proceeding. We have made some low energy radiographs of free-standing coating layers. Eddy current characterization measurements on free-standing coating layers are in progress. Some additional progress in ultrasonic detection of unbonds and missed areas has been made. We are developing new analytical methods for electrochemical data and clearing up some minor experimental problems. We successfully generated plots of crack structures from high voltage probe data. The ability to record an image of 1 arge rracks has been demonstrated.

- The rate of formation of iron carbonyl by reaction of a synthesis gas with $1 / 2 \%$ Mo steel was shown to be pressure- and temperature-dependent. The formation rate was shown to decrease with increasing temperature above about $200^{\circ} \mathrm{C}$ for some conditions.

- The final report on a failure analysis of a Synthoil letdown valve is in press. The final report on the condition of carbon steel combustor tubing from PERC is drafted. An investigation of an Alloy 601 MHD combustor tube from PERC was initiated.

- The conceptual design of a HYGAS Prestressed Concrete Pressure Vessel system was essentially completed. Materials and detailed thermal analysis considerations were emphasized.

- Work on cladding carbon and low-alloy steels with Alloy 20 has been initiated with a literature survey, procurement, and trial welding parameter studies.

- 'lhe first surveillance tubes exposed in a Fluidyne Corporation fluidized bed combustor were received at ORNL for analysis.

- In our gas-fired potassium boiler project, we completed tests with argon and water to prove that there will be a satisfactory distribution of boiling nucleation sites, continued testing of the boiler with water, and proceeded with the design and fabrication of components that will be needed when we begin tests with potassium.

- In our design study of a Coal-Fired Alkali Metal Vapor Topping Cycle, we completed the compilation of physical and thermodynamic properties of cesium and potassium, continued the conceptual design of a vertical-tube natural circulation boiler, and began conceptual design studies of turbines for application to cesium and potassium. 
- A subcontract was given Stearns-Roger, Inc., to assist in the investigation of the detailed component testing module requirements of a critical components test facility on a "nonsite-specific" basis. The test modules to be considered in the current effort are the valve test module, slurry pump test module, coal feeder test module(s), and gas cleanup system test module.

- In our engineering studies and technical support work, we continued the development of a product pricing subprogram for the process modeling study, began writing an initial article for the Process Research Digest, developed a detailed work schedule for our survey of industrial equipment capabilities, and initiated studies on the economies of scale in large air separation plants.

- Process and program analysis research studies were continued with work on low-Btu gasification, direct combustion, advanced power conversion systems, in situ coal gasification, coal beneficiation, gas cleanup, and costs of transporting energy.

- Our first major deliverable in our Fossil Energy Environmental Assessment Project was completed this month. This was a document that is intended to establish the requirements for environmental impact assessments that are to be included in responses to Requests for Proposals.

- In our Coal-Fueled MIUS program, project review by ERDA/Fossil Energy continued with respect to future funding and possible redirection of the program. All the detailed design work has been temporarily halted because of uncertainties related to furnace design and use of the gas turbine. The coal and limestone feed systems and cold flow model tests are applicable to any-furnace design and these will be continued until they are completed. 


\section{COAL CONVERSION PROCESS DEVELOPMENT}

J. R. Hightower, Jr.

Coal conversion process development activities are carried out in the Chemical Technology Division. This section discusses hydrocarbonization studies in a 20-atm bench-scale facility, studies of residue carbonization in an atmospheric pressure carbonizer and in a pressurized carbonizer, engineering support studies for in situ gasification, and studies for identifying and characterizing alternate reactor concepts for coal hydroliquefaction.

\subsection{Hydrocarbonization Research}

H. D. Cochran, Jr., P. R. Westmoreland, C. H. Brown, Jr., J. Beams, J. C. Rose, and L. S. Dickerson

Routine experimentation continued in November:

$\mathrm{HC}-9$ - Recirculating fluidized bed reactor at $950^{\circ} \mathrm{F}$ and 300 psig $\mathrm{H}_{2}$ pressure, Wyodak subbituminous coal fed at $6.8 \mathrm{lb} / \mathrm{hr}$ for $4.8 \mathrm{hr}$.

Samples and data from this experiment are being analyzed. Material balances will be reported in the December monthly report.

Preliminary data analyses for experiment $\mathrm{HC}-8$ have been completed. As expected, low liquid and gas yields resulted from the low temperature of $800^{\circ} \mathrm{F}$, with the principal gas components being $\mathrm{CH}_{4}$ and $\mathrm{CO}$.

Gas analyses from Run HC-9, at the higher temperature of $950^{\circ} \mathrm{F}$, show an increase in $\mathrm{CH}_{4}$ and $\mathrm{CO}$ levels, and a decrease in $\mathrm{CO}_{2}$.

Flexicon ${ }^{*}$ flexible conveyor tubing will be ordered during December for the grinding-sieving equipment, permitting more efficient coal preparation.

Routine experimentation will continue in December with a recirculating fluidized bed run at 300 psig and approximately $1050^{\circ} \mathrm{F}$.

\subsection{Residue Carbonization}

H. D. Cochran, Jr., J. B. Gibson, R. L. Andrews, and J. R. Cox

The analytical data on the recovered tars from $\mathrm{RC}-16$ and $\mathrm{RC}-17$ are shown in Table 2.1 along with the data from the H-Coal residue, the feed mixture ( $4 / 1$ char to residue), and residue carbonization product char. The ash contents of the tars recovered from the scrubber in RC-16 and the

\footnotetext{
${ }^{\star}$ Trademark.
} 
Table 2.1. Ultimate and proximate analysis of feed and product materials in residue carbonization

\begin{tabular}{lcccc}
\hline & $\begin{array}{c}\text { Ash } \\
(\%)\end{array}$ & $\begin{array}{c}\text { Moisture } \\
(\%)\end{array}$ & $\begin{array}{c}\text { Volatile } \\
\text { material } \\
(\%)\end{array}$ & $\begin{array}{c}\text { Fixed } \\
\text { carbon } \\
(\%)\end{array}$ \\
\hline Proximate Analysis
\end{tabular}

$a_{\text {By difference. }}$ 
string filter housing in $\mathrm{RC}-17$ is a lower percentage than the feed. The amount of volatile material in the tars is more concentrated than the feed.

Three residue carbonization runs were attempted during November with equipment changes to facilitate operation. All three attempts were made with a $4 / 1$ char to residue feed mixture and resulted in tar product from the scrubber. Run RC-17 used an internal cyclone and draft tube. The run was interrupted by a plugged feed nozzle and halted by a plugged cyclone after a total run time of $45 \mathrm{~min}$. Two and one-half pounds of char/residue were fed. Run RC-18 was operated as a spouted bed without cyclone and draft tube. The annulus around the feed nozzle was cooled by gas in an attempt to prevent plugging in the feed nozzle. The run lasted $1 \mathrm{hr}$, feeding $31 / 2 \mathrm{lb}$ of char/residue mixture, The run was restarted once after a delay caused by the effluent lines plugging. In RC-19 the draft tube was reinstalled, the reactor effluent line was changed to l-in. tubing, and the feed nozzle was insulated. The string filter plugged and was changed twice during the run. A greenish aerosol was emitted by the system while changing the string filter. The repeated plugging downstream caused a loss of feed and abortion of the run. The run was interrupted once with a total time of $30 \mathrm{~min}$ and $2 \mathrm{lb}$ of mixture fed.

The scrub liquid will be changed from water to an organic solvent in order to eliminate the aerosol mist which escaped the scrubber in RC-19. Also methods of preventing and removing plugs during runs in the feed nozzle will be considered as will. a change to a slurry feed.

\subsection{Experimental Engineering Support of an Iu Silu Gasiflcation Process}

R. C. Forrester III, G. D. Owen, S. M. Gibson, and J. D. Cohil1

\subsubsection{Large-Block Pyrolysis Studies}

Two experiments were carried out during this report period, both of which involved pyrolysis at $3.0^{\circ} \mathrm{C} / \mathrm{min}$ to maximum temperatures of 500 and $600^{\circ} \mathrm{C}$. Both tests produced extremely pyrophoric chars which had to be extinguished to avoid self-ignition after brief exposure to the atmosphere. One more experiment is planned to complete program objectives with respect to two-dimensional pyrolysis of western, subbituminous coals at atmospheric pressure under an inert gas atmosphere.

Equipment changes necessary for tests under reducing gas atmospheres are underway, and samples of some eastern coals (characteristic of those to be gasified by the Morgantown Energy Research Center in situ field test) will be available in two weeks. 


\subsubsection{ERDA's UCG Program}

Detailed technical review of the ORNL program supportive of in situ gasification development was conducted this month at ERDA headquarters in Washington. A presentation of program objectives, recent results, and proposed activities in FY 1978 was made and followed by critical analysis by meeting attendees.

\subsection{Coal-Solvent-Hydrogen Mixing}

J. R. Hightower, Jr., and R. C. Lovelace

The objective of the work reported here is to demonstrate that a highly turbulent plug flow reactor of novel design would allow adequate hydrodesulfurization and hydroliquefaction without the use of hydrotreating catalysts. The present work plan calls for two phases: (1) simulated contactor studies which have the objective of identifying suitable reactor configurations (we will investigate a reactor consisting of several venturis in series and one with vortex flow similar to a cyclone device) through tests with water/coal slurries and air, and (2) hydrogenation verification studies in which coal is hydrogenated in a suitable reactor whose design would be based upon results from the first phase studies.

About 20 gal of coal/water slurry containing about 37 wt \% coal was added to the 55-gal surge tank in the slurry circulation loop. This slurry was agitated and recirculated through an eastern pump and back to the surge tank to determine if the coal composition of flowing streams differed from the average composition in the surge tank and to determine if flowing through the pump changed the particle size distribution. With a slurry circulation rate of $.4 \mathrm{gal} / \mathrm{min}$ flowing stream samples and grab samples taken from the agitated surge tank after $4 \mathrm{hr}$ and $7 \mathrm{hr}$ of circulation showed coal concentrations to be 37 wt \% coal in all samples. This test will be repeated at slurry flow rates near 1-2 gal/hr, which will be the range of flow rates examined in the packed column. Size distribution analyses of samples taken after $\mathrm{l} \mathrm{hr}$ and $7 \mathrm{hr}$ of circulation showed no signiflcant change in particle size distribution during pumping.

Pulses of $0.075 \mathrm{M} \mathrm{KCl}$ traces were injected into the packed column to test techniques for measuring dispersion. In the first test the pulse at the inlet to the column was sharp, well-defined, and appeared to be normal (maximum reading on the recorder was $\sim 40 \%$ of full scale). The pulse at the column outlet was more dispersed (as would be expected) but the maximum amplitude was only about $3-4 \%$ which was much lower than expected. The alumina packing was removed from around the concentration cell at the column outlet and the test was repeated. This time the inlet pulse (which should not have been affected) was slightly smaller ( $30 \%$ of full scale) and the outlet pulse was again dispersed but had a higher maximum value ( $\sim 40 \%$ ) than the inlet pulse. We are investigating the reasons for this unexpected behavior, since it indicates that our techniques have some error in them. 


\subsection{Pressurized Carbonization of Consol Synthetic Fuel Solid Residues}

J. R. Hightower, Jr., J. B. Gibson, and S. M. Gibson

Fluor Engineers and Constructors is designing a plant using the Consol Synthetic Fuel (CSF) process for ERDA in which they are considering pressurized gasification of carbonized hydroclone underflow for hydrogen production. In order to avoid lock hoppers, they plan to pressurize the carbonizer and allow the char simply to overflow from the carbonizer to the gasifier. The hydroclone underflow will be slurried with a recycle oil (some of the donor solvent) and pumped into the carbonizer. The oil would be vaporized and recovered. Fluor would like to know how much of the recycle nil would be thermaliy degraded and what residence times would be required to vaporize the oil from the solids at $900^{\circ} \mathrm{F}$ and 50 and 400 psig. ORNL has been asked to provide quickly some information on these subjects. An experimental batch pressurized carbonizer using $1 \mathrm{~kg}$ (or less) quantities of hydroclone underflow and recycle oil will be used to estimate the fractional recovery of recycle oil and the fate of any thermally degraded oil.

In the proposed pressurized carbonization experiment (diagrammed schematically in Fig. 2.1) $\sim 200 \mathrm{~g}$ of a slurry of the composition anticipated in Fluor's flowsheet is fed by controlled pressurization of a feed tank to a heated carbonizer vessel. In the carbonizer the slurry is dispersed with heated argon using a two-fluid nozzle and thereafter it is carbonized. The solids produced from carbonization are collected in the carbonizer vessel. Gases and vapors are filtered and the vapors condensed and collected in a cold trap. Samples of the cold gases are collected in evacuated sample bombs for analysis and the total volume of gases evolved is measured. At the conclusion of the experiment the solids and liquids are removed from the equipment for weighing and analysis. Thus, material balances can be made to determine the extent of degradation of solvent to carbon and gases.

Eight experiments will be run to cover two values of gas residence time, two pressures (50 and $400 \mathrm{psig}$ ), and two temperatures ( 900 and $1050^{\circ} \mathrm{F}$ ). Ultimate analyses will be made of feed materials and of products to allow calculation of solvent losses.

The major equipment items shown on the flowsheet have been designed and engineering drawings are being prepared. In the carbonizer vessel the slurry will be atomized into a fluidized bed of alumina. A two-fluid atomizing nozzle suitable for handling a viscous slurry has been designed and it operates satisfactorily with water. The atomizing gas is also used to fluidize the bed of alumina. The experiment will be installed in a hood in Building 3541. The high pressure regulators and valves have been ordered. Foxboro DP cells with integral orifices will be used to measure gas flow rates, and these are on hand. 


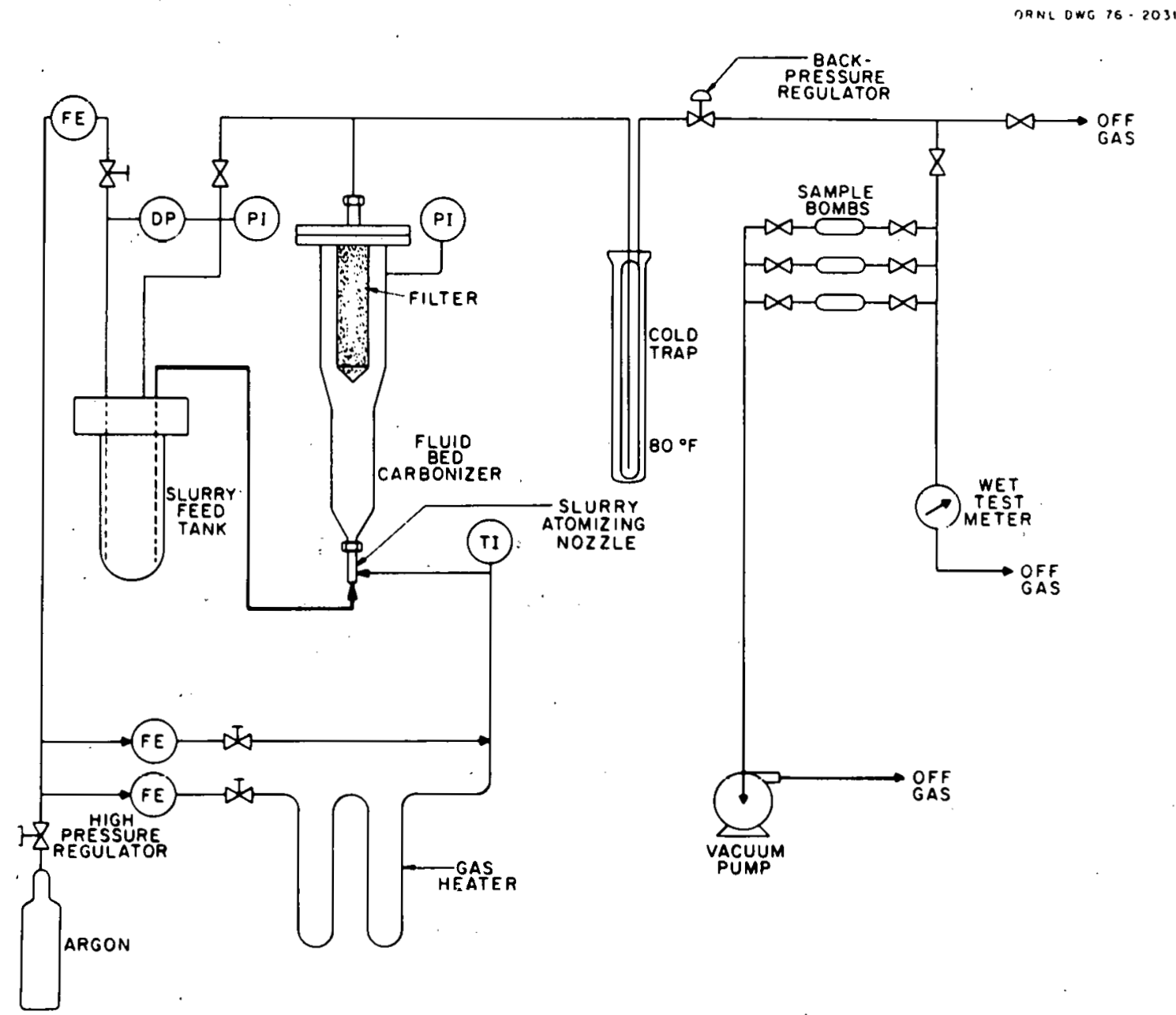

Fig. 2.1. Flow diagram of pressurized carbonization experiments. 


\title{
3. MATERIALS ENGINEERING
}

\author{
R. T. King and D. A. Canonico
}

The materials engineering and associated technology reported here are in support of activities directed by the Materials and Power Generation Branch of the Division of Fossil Energy Research. Other related work not funded directly by this division of ERDA/F' is included also.

\section{Summary}

A draft of the report, Assessment of Materials Technology of Pressure Vessel and Piping for Coal Conversion (ORNL-5238) has been completed. Procurement of several pressure vessel steels for heat treatment and characterization studies was completed.

Several activities for inspection of wear and process-resistant coatings are being pursued. We have contacted Argonne National Laboratory for a direct update on coating selection work. We have contacted coating Systems Technology to discuss duplication of ANL specimens and have requested ANL to release technical data relative to these specimens. Purchasing activities for our $x$-ray fluorescence system are proceeding. We have made some low energy radiographs of free-standing coating layers. Eddy current characterization measurements on free-standing coating layers are in progress. Some additional progress in ultrasonic detection of unbonds and missed areas has been made. We are developing new analytical methods for electrochemical data and clearing up some minor experimental problems. We successfully generated plots of crack structures from high voltage probe data. 'l'he ability to record an image of' large cracks has been demonstrated.

'The rate of' formation of' iron carbonyl by reaction of a synthesis gas with $1 / 2 \%$ Mo steel was shown to be pressure- and temperature-dependent. The formation rate was shown to decrease with increasing temperature above about $200^{\circ} \mathrm{C}$ for some conditions.

The final report on a failure analysis of a synthoil letdown valve is in press. The final report on the condition of carbon steel combustor tubing from PERC is drafted. An investigation of an Alloy 601 MHD combuctor tube from PERC was initiated.

The conceptual design of a HYGAS PCRV system was essentially completed. Materials and detailed thermal analysis considerations were emphasized.

Work on cladding carbon and low-alloy steels with Alloy 20 has been initiated with a literature survey, procurement, and trial welding parameter studies.

The first surveillance tubes exposed in a Fluidyne Corporation fluidized bed combustor were received at ORNL for analysis. 


\title{
3.1 Pressure Vessel and Piping Technology Assessment
}

D. A. Canonico, R. H. Cooper, B. E. Foster, R. K. Nanstad G. C. Robinson, and G. M. Slaughter

A review of the piping and pressure vessel needs for coal conversion systems is in progress. The program will identify those areas where additional property data needs are required in order to assure that the pressure boundary components in conversion systems can be designed, fabricated, and operated in a safe and reliable manner.

The draft of the report, Assessment of Materials Technology of Pressure Vessels and Piping for Coal Conversion (ORNL-5238), is complete. It has been edited and is currently being reproduced for submittal to Fossil Energy Research. The abstract for the report is as follows:

The current technology of the design, materials, fabrication and inspection of pressure vessels and piping for commercial coal conversion systems is reviewed. Comparison is made between the various Codes applicable to these conversion systems. Areas of concern, such as material compatibility and fracture toughness are cited. Recommendations are made that should increase the reliability of these components, the failure of which would result in a major outage of the plant.

The article for the ERDA Newsletter was reviewed and returned to Battelle Memorial Institute.

A $0.9 \mathrm{~m}$ by $0.9 \mathrm{~m}(3 \times 3 \mathrm{ft}$ ) piece of $254 \mathrm{~mm}$ (10 in.) thick A 543 Class 1 steel plate has been obtained and is being sectioned. Samples of various heats of $21 / 4 \mathrm{Cr}-1$ Mo steel (analysis similar to SA 387 Grade 22 and SA 336 F22) have been obtained. These will be heat treated in the Datatrak to simulate the surface and $1 / 2$ thickness properties of $30.5 \mathrm{~mm}$ (12 in.) thick pressure vessel steels.

\subsection{Inspection Techniques for Wear- and Process-Resistant Coatings}

\author{
R. W. McClurig and G. W. Scott
}

\subsubsection{Review and Evaluation (G. W. Scott)}

We are experiencing delays in getting information on coating selection work at Argonne National Laboratory (ANL). Recent inquiries to ANL requesting an update have apparently been hampered during their transition between Coal Technology Program Coordinators. 


\subsubsection{Specimen and Standard Fabrication (G. W. Scott)}

We have established communications with Coating Systems and Technology, Inc., (CST), the major firm supplying specimens and developing coating methods for. ANL. However, there are provisions in the CST-ANL contracts which prohibit CST from duplicating ANL specimen types for us and giving us data on materials or application methods used for the ANL specimens. We have written to W. A. Ellingson, CTP coordinator at ANL, requesting release of the technical data available from CST.

\subsubsection{Penetrating Radiation (G. W. Scott)}

Bids for our x-ray fluorescence measurement system have been received and evaluated. A recommendation for procurement has been sent to UCCND Purchasing Department for action.

We have made some low energy radiographs of free standing coating layers. The objective is to determine the feasibility of the technique as an aid to coating characterization. We are still evaluating the results and modifying the technique.

\subsubsection{Eddy Current (G. W. Scott and C. V. Dodd)}

We have made through transmission amplitude and phase measurements at $1 \mathrm{MHz}$ on free-standing layers of $\mathrm{NiCrAl}(75-24-1)$ and 50- $\mathrm{NiCrAl} / 50-\mathrm{ZrO}_{2}$. We are comparing the measurements with calculations in a search routine to determine the effective conductivity and permeability of these materials. The aggregation state of the sprayed layer significantly affects the electrical properties and makes measurements of this type necessary for useful characterization.

\subsubsection{Ultrasonics (G. W. Scott)}

We have continued experiments with the multiple-echo technique described in the last report. Usable results were obtained at 15, 10 , and $5 \mathrm{MHz}$ with about the same sensitivity as previously obtained at $25 \mathrm{MHz}$. As the frequency decreases, the echo pulses become wider, i.e., they persist for a longer time, so that the individual echoes become more difficult to identify and the test is harder to set up correctly. However, the lower frequency offers some improvement in transducer efficiency and lessened sensitivity to small internal flaws in the substrate material.

\subsubsection{Electrochemical Testing (G. W. Scott)}

We examined some additional techniques for analyzing and displaying the electrical data from earlier experiments. A complex admittance plane representation seems to provide the easiest analysis and best display. 
From these analyses, some conclusions about useful measuring devices can be drawn. Analysis of data thus far obtained indicates that an unbalanced bridge device, set up for maximum amplitude sensitivity, would make a good instrument.

We are working on experimental techniques to remove some of the sensitivity to geometry and to eliminate the effects of meniscus formation at the surface of the electrolyte where the electrodes enter. The presence of a meniscus has been shown to affect the results obtained thus far.

\subsubsection{High Voltage Testing (G. W. Scott)}

By making repeated line scans across a tensile-cracked specimen, we have been able to plot a crude map showing two large cracks in the specimen. These plots resemble a photo of the filtered-particle indications on the same specimen. The photo shows a number of smaller crack indications for which no corresponding arc current signals were obtained. We do not know if the various cracks differ in any way other than size. We are making various adjustments to the technique to see if sensitivity to the smaller cracks can be improved.

\subsection{Iron and Nickel Carbonyl Formation and Prevention}

$$
\text { J. H. DeVan, H. Inouye, and J. Brynestad }
$$

The generation rate of iron carbonyl resulting from the reaction of a $1 / 2 \%$ Mo-steel with a 1000 psi gas mixture containing $17 \mathrm{CO}-5 \mathrm{IH}_{2}-30 \mathrm{CH}_{4}-2 \mathrm{CO}_{2}$ (in vol \%) increases with temperature to a maximum value of about $22 \mathrm{~g}$ $\mathrm{Fe}(\mathrm{CO})_{5} / \mathrm{ft}^{2} / \mathrm{yr}$ at $177^{\circ} \mathrm{C}$. Above this temperature the rate decreases sharply to a value of $0.35 \mathrm{~g} \mathrm{Fe}(\mathrm{CO}) 5 / \mathrm{ft}^{2} / \mathrm{yr}$ at $266^{\circ} \mathrm{C}$. Extrapolation of the data indicates that no iron carbonyl should form at about $275^{\circ} \mathrm{C}$. In contrast, Il $\mathrm{g} / \mathrm{ft}^{2} / \mathrm{yr}$ of iron carbonyl forms when the steel. is exposed to $170 \mathrm{psi}$ of pure CO at $266^{\circ} \mathrm{C}$ (i.e., for the same $P_{C O}$ as in the mixed gases). The 316 stainless steel autoclave is concluded to be the source of about $1-\mathrm{ppb}$ of nickel carbonyl detected in the effluent gases. Our measurements indicate that the generation rate of nickel carbonyl is also flow, temperature, and pressure dependent. A detection limit of $\pm l \mathrm{ppb}$ of nickel carbonyl has been established for the spectrophotometer.

\subsection{Failure Prevention and Analysis}

A completed failure analysis of a Synthoi.l process letdown valve has been written as a technical memo, and is in press.

A post-service analysis of carbon steel combustor tubes from each of the three final passes through an oil-slurry-fired boiler run at PERC was completed and the results were made available at PERC. The final report has been drafted. 
An alloy 601 Inconel preheated air line from the PERC MHD experiment experienced an apparent burn-through failure. A section of the failed pipe was received at ORNL and a failure analysis was initiated.

\subsection{Prestressed Concrete Pressure Vessel Studies}

W. L. Greenstreet

The objective is to investigate the potential use of prestressed concrete pressure vessels (PCPV) for coal conversion processes, to identify major problem areas, and to define and outline a test program (or programs) t'or feature and concept demonstration. Conceptual designs of pressure vessel and liner combinations for commercial size systems are to be developed and studied as vehicles for assessment and guidance.

Significant progress was made during this month on thermal analyses and conceptual design work. Structural material and refractory studies were reactivated.

Under task 1 , the conceptual design of the HYGAS vessel was essentially completed and design layouts made. Quantities of materials are being calculated and descriptions of the materials prepared. Information necessary for making cost estimates for steel and concrete vessels is being summarized in preparation for cost comparisons.

Under task 4, mechanical behavior of combined 0.10-m (4-in.) thick hard face refractory and $0.20-\mathrm{m}$ (8-in.) thick insulating refractory are being studied. Other material selections have been made, and effects of hydrogen on prestressing tendons are being estimated.

Thermal analyses were completed on various candidate configurations for the hot-liner concept. The configuration established makes use of $0.30 \mathrm{~m}$ (12 in.) of refractory lining $[0.10 \mathrm{~m}$ ( $4 \mathrm{in.}$ ) of hard face and $0.20 \mathrm{~m}$ ( $8 \mathrm{in.}$ ) of insulating] inside the steel liner and $0.083 \mathrm{~m}$ (3.25 in.) of insulating concrete outside. Finned tubes $[0.025 \mathrm{~m}$ ( 1 in.) in diameter with two diametrically-opposed straight fins lying in vertical planes] are required in $0.15-\mathrm{m}$ (6-in.) spacings. The controlling temperatures are well within specified limits for the reference configuration; during postulated cooling circuit malfunction resulting in an effertive tube spacing of $0.30 \mathrm{~m}$ ( $12 \mathrm{in.}$ ), the maximum concrete temperature is at the $405 \mathrm{~K}\left(270^{\circ} \mathrm{F}\right)$ limit. When a $0.0016-\mathrm{m}(0.0625-\mathrm{in}$.$) annular air gap is$ assumed to exist around each tube, the maximum concrete temperature is about $42^{\prime} \mathrm{K}\left(300^{\circ} \mathrm{F}\right)$, or about $10 \%$ above the quoted maximum allowable temperature. In both off-design cases, the maximum liner temperature does not exceed acceptable limits.

Local temperature distributions are now being examined. Included are temperatures in the vicinities of liner-to-concrete anchors and of refractory anchors. 
Test program definitions, as required under task 6 , are being addressed. A number of areas requiring experimental investigation or demonstration of acceptable performance were defined, and tentative test program outlines were prepared.

In summary, success achieved in the thermal analysis area has provided needed bases for reactivating and completing related studies. Good progress was made in several areas during this month.

\subsection{Cladding with Alloy 20 \\ D. P. Edmonds}

We are developing techniques for cladding of carbon and low-alloy steels with a corrosion-resistant layer of Alloy 200 stainless steel. Presently a literature review is being performed on the subject of submerged-arc and gas metal-arc cladding with this alloy. We are now obtaining Alloy 20 wire from a commercial manufacturer to begin developmental work. Also, we are investigating the effects of welding conditions on the dilution and bead contours of type 308 clad metal deposited with the submerged-are process. Conditions being investigated are welding current, voltage, travel speed, pre-heat temperature, and polarity. Information gained from this study can be used for Alloy 20 cladding materials.

\subsection{Fluidized Bed Combustion}

R. H. Cooper, Jr., and J. H. DeVan

In previous monthly reports preparations of surveillance tube segments of Incoloy 800 , Inconel $600,310,304$, and 316 stainless steel for exposure to a fluidized bed coal combustor environment have been reported. During this reporting period the first 500 hours of continuous exposure in a fluidized bed operated by the Fluidyne Corporation was completed. The tubes were removed, visually inspected, and shipped to ORNL for detailed examination. Visual inspection revealed an ash deposit on the surface of these tubes. This deposit was noted to be tenaciously adherent to the surface of Inconel 600 while tending to slowly spall off the surfaces of the remaining materials. This visual inspection did not reveal any signs of significant corrosion attack.

While at ORNL these tubes sections will be eddy current inspected and selected tube sections will be destructively inspected. Based on the results of this inspection and a review of information describing the operation of the fluidized bed combustor during this initial 500 hour run, a contract for an additional 500 to 1000 hour of run time may be requested. In this case the present tubes will be reinserted, giving them an accumulated exposure time of 1000 to 1500 hours in this fluidized bed environment. 


\section{ALKALI METAI, VAPOR TOPPING CYCLES}

R. S. Holcomb and G. Samuels

\subsection{Potassium Vapor Cycle}

R. S. Holcomb, R. H. Guymon, and D. B. Lloyd

\subsubsection{Design}

Three drawings were released for construction including one assembly drawing. The others included the condenser housing closure and a thermocouple junction box. Work continued on the potassium rondensate return piping, the vapor separator modification, and condenser housing exhaust stacks.

Routing for thermocouples on the condenser and gas separator has been established, and the drawings are in progress. The design of the level element for the vapor separator is nearing completion. Work was begun on the support tower extension drawings.

\subsubsection{Fabrication}

The condenser enclosure, including the inlet and outlet plenums, has been completed except for some insulation. The gas separator has been fabricated and mounted inside the condenser. Work on the piping between the condenser and gas separator was begun. The thermocouples that will be attached to the condenser and gas separator have been sent to the shop to have the attachment lugs brazed onto the tips. Fabrication of the level element for the fill-and-drain tank is nearing completion. The air control dampers for the condenser enclosure have been ordered and are scheduled for delivery by February 1, 1977. Work was begun on refurbishing existing power supply cabinets.

\section{1 .3 System Operation}

An analysis was made of the data on argon distribution in the botler, and it was decided that all the evidence supports the fact that there is adequate argon distribution in the boiler tubes. Further testing will not be conducted.

The steam sampler installed last month was used to determine the uniformity of flow distribution through the various boiler tubes at different power levels. Several runs were made at a burner power of about 2 million Btu's per hour. Analysis of the data from these runs is not yet completed. The unseasonably cold weather has on occasion made operation of the system significantly more difficult. Numerous precautions have been taken to avoid damage to the system by the cold weather.

\subsubsection{Schedule}

A new project schedule was developed, based on the present design of the system. The schedule is shown in Fig. 4.1. 


\begin{tabular}{|l|l|l|l|l|l|l|l|l|l|l|l|l|}
\hline NOV & OEC & JAN & FEB & MAR & APRIL & . MAY & JUNE & JULY & AUG & SEPT & OCT \\
\hline
\end{tabular}

ASSEMBLE OWGS, TO RUST TUST NEGOTIATIONS ANO SCH. O.T. CONOENSER. SAMPLE BOX, TOWE

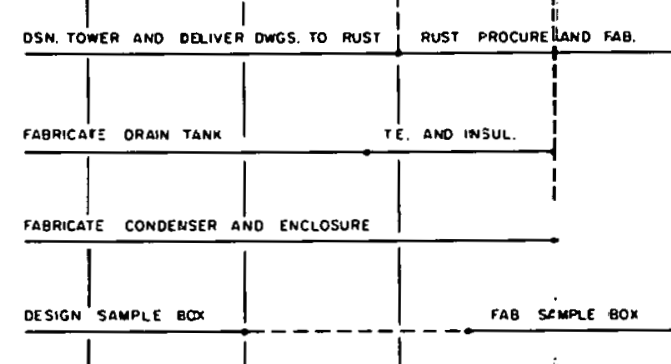

ORAIN TAMK.

CONDENSER : 8

ENCLOSURE

SAMPLE $3 C X$

PIPING

WATER TEST

$18 \mathrm{c}$

ELECTRICAL

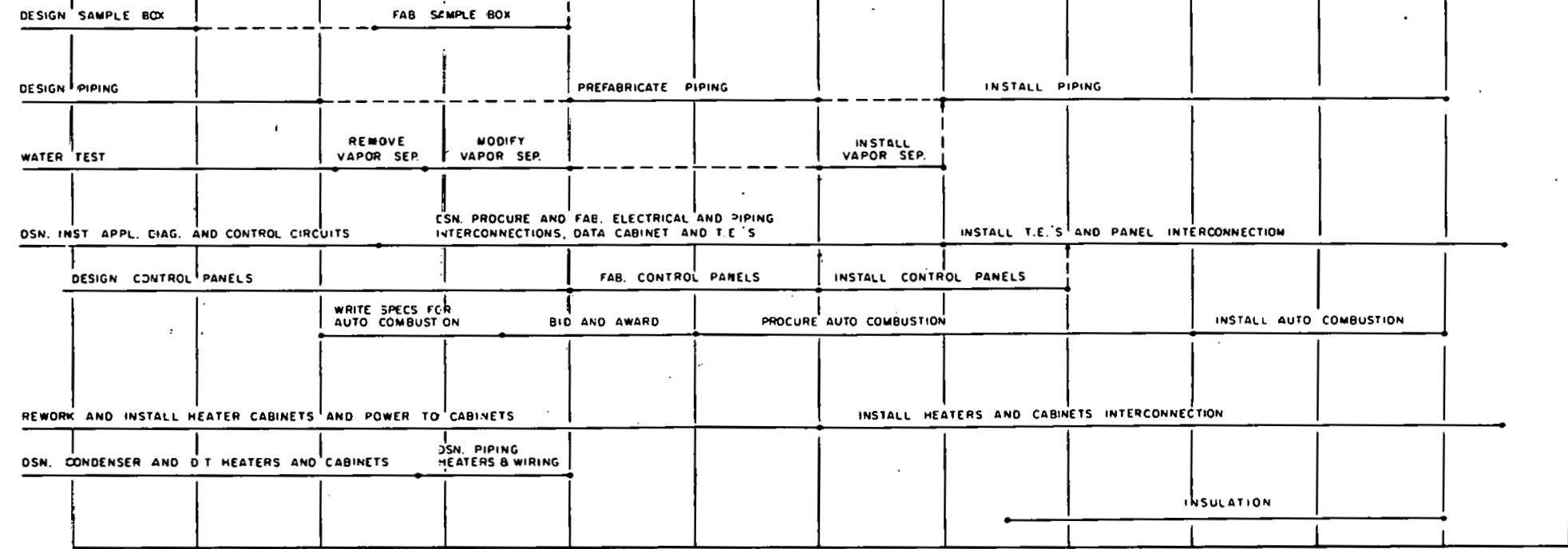

Fig. 4.1. Potassium vapor topping cycle schedule. 


\subsection{Coal-Fired Alkali Metal}

\section{G. Samuels}

The compilation of physical and thermodynamic properties of cesium and potassium was completed. The basic thermodynamic data used were that published by Ewing et al., in NRL Reports 6233 and 6246. Computer codes using these data were prepared to extend the range of properties to lower temperatures of interest to the current studies. Mollier diagrams have been prepared for the temperature range of $1050^{\circ} \mathrm{F}\left(583^{\circ} \mathrm{K}\right)$ to $2300^{\circ} \mathrm{R}\left(1278^{\circ} \mathrm{K}\right)$ for cesium and from $1200^{\circ} \mathrm{R}\left(667^{\circ} \mathrm{K}\right)$ to $2300^{\circ} \mathrm{R}\left(1278^{\circ} \mathrm{K}\right)$ for potassium. The wet region for both diagrams extends down to $28 \%$ mnisture,

Work was started on "roughing out" the designs of turbines for both cesium and potassium. The purpose of these designs, at this stage, is primarily to determine the losses to be expected and to arrive at turbine efficiencies to be used in the cycle analysis. Initial results of calculations to determine the effects of supersaturatign indicate a loss ranging between $2 \%$ for a stage $\Delta \mathrm{h}$ of $11 \mathrm{Btu} / 1 \mathrm{~b}\left(25.6 \times 10^{3} \mathrm{~J} / \mathrm{kg}\right)$ to $4 \%$ for a $\Delta \mathrm{h}$ of $15 \mathrm{Btu} / \mathrm{lb}\left(34.9 \times 10^{\mathrm{J}} \mathrm{J} / \mathrm{kg}\right)$ for cesium. Comparable figyres for potassium are a loss of $2 \%$ for a stage $\Delta \mathrm{h}$ of $35 \mathrm{Btu} / 1 \mathrm{~b}\left(81.4 \times 10^{3} \mathrm{~J} / \mathrm{kg}\right)$ and $4 \%$ for a $\Delta \mathrm{h}$ of $60 \mathrm{Btu} / \mathrm{lb}\left(140 \times 10^{\mathrm{J}} \mathrm{J} / \mathrm{kg}\right)$. These results are based on the assumption that the return to equilibrium occurs along a constant pressure path.

Data are also being compiled on the cycle efficiency of steam systems for various cycle conditions. These data are needed to study the effects of varying the alkali metal condenser-steam boiler temperature on the overall plant efficiency.

Design work was continued on a vertical-tube natural-circulation boiler. These designs have all used a triangular array of 1 -in.-OD tubes on 2-in. centers. 


\section{CRITICAL COMPONENTS TEST FACILITY}

\section{R. E. MacPherson}

The internal reviews and ERDA-ORO reviews of the reports on the CCTF and VTM feasibility studies, X-OE-25 entitled."Feasibility Study for Critical Components Test Facility" and X-OE-26 entitled "Feasibility Study for Coal Process Valve Testing," continued through the month.

At the request of ERDA-FE, an informal report was prepared and submitted to them which discussed the advantages of an integrated component test. facility and the resources of Oak Ridge which would be advantageous in locating that integrated test facility here. The report points out that, since the need for test evaluations of critical components for use in demonstration plants is established, consideration must be given to the most effective way to accomplish the testing. Possible approaches include the use of available operating facilities in industry, adaptation of equipment in government sponsored development programs, and establishment of. dedicated facilities at multiple sites or at a single site. Those possibilities were discussed in the report, and it was concluded that a single site for an integrated CCTF presents the best approach to a flexible, responsive, and effective test program.

A subcontract was given Stearns-Roger, Inc., to assist in the investigation of the detailed component testing module requirements of a CCTF on a "nonsite-specific" basis. The test modules to be considered in the current effort are the valve test module, slurry pump test module, coal feeder test module(s), and gas cleanup system test module. Stearns-Roger, Inc., has experience in the design of demonstration plant equipment and the special problems associated with the components required for the processes being considered. Their work on this contract is scheduled for completion by January $21,1977$. 


\title{
6. ENGINEERING STUDIES AND TECHNICAL SUPPORT
}

\author{
J. R. McWherter
}

\subsection{Process Modeling Support}

R. Salmon, D. S. Joy, and D. Lister

On November 8, 1976, D. Joy, D. Lister, and R. Salmon of ORNL visited Purdue University to discuss progress by Purdue and ORNL on the joint Purdue-Lehigh-ORNL process modeling effort. Short presentations were given by six members of the Purdue team working on the project. The following topics were discussed:

- Detailed discussion of some of the software produced with respect to the iterative processes used, sophisticated core storage techniques, and user-oriented options.

- Pyrolysis of coal with particular emphasis on kinetics of volatilization.

- Mathematical model of a batch reactor.

- Techniques for the solution of a material balance flowshect.

- Data collection and analysis for estimation of plant investment costs.

ORNL was given copies of cost data and several computer programs, including a multicomponent distillation code.

A joint project review meeting was held in Washington, D.C. on November 17, 1976. Representatives of Lehigh, Purdue, ERDA, and ORNL were present. This meeting followed the ERDA Conference on Computerized Mathematical Modeling of Coal Conversion Processes, which was held on November 16. At the November 17 meeting, status reports were presented by each of the groups. Purdue plans to have the physical data package and basic material balance program operational by January 1977, and to have a preliminary overall flowsheet model operational by the summer of 1977. The delay in COED-COGAS data acquisition was discussed.

At ORNL, work continued on the computer program PRP (product price), which calculates the production cost of products from a coal conversion plant. The program was operational in September and was used in the hydrocarbonization and Synthoil evaluations; however, several new options are being added which will make the program more useful. The program uses the discounted cash flow procedure. It produces a parametric study of product price in which both coal price and rate of return on equity can be varied through any desired range. Taxes are calculated internally. Provisions for handling investment tax credits, tax-loss carry-forward, and interest during construction are made. Plant operating factor can 
be varied from year as desired. Investments throughout the construction period can be specified. A report is in preparation documenting the program and giving instructions for its use. A copy of the source deck of the program was supplied to Purdue.

Work continued at ORNL on a computer program that calculates a piping layout, determines process piping diameters and lengths, and makes an overall piping cost estimate for a process plant. The user inputs the grid coordinate locations of the major process equipment, the rates of flow through the various process lines, and the routing of the process lines in terms of the process equipment items. Pressure drops desired are specified in terms of allowable psi per $100 \mathrm{ft}$. The program calculates line sizes, pressure drops, line routings, lengths, and costs. Factors will be applied to account for small miscellaneous lines. We believe that a cost estimate made in this way will be a considerable improvement over one made by conventional procedures in which factors are directly applied to process equipment costs. Also, the program will permit more direct estimation of the costs of insulation, painting, and pipe supports.

\subsection{Process Research Digest}

F. J. Endelman

All contractors of projects, which are scheduled to be reported upon in the first issue of the Digest, were contacted by mail in November. Each was given a list of the reports on their project which we have on hand, and asked to refer us to other documents which they felt could provide a more complete understanding of the historical background, past accomplishments, current status, and future tasks of their project.

Mobil Research and Development Corporation promptly responded to our request with substantial information. We are proceeding to write the article on their project for converting methanol to gasoline. Brookhaven National Laboratory also promptly responded, but it appears as if more detalled information will be requested of them. As reported last month, work on the article on rapid hydropyrolysis, of which the Brookhaven project is a part, has already commenced.

None of the remaining five contractors have responded to our request for information. They will each be contacted by phone in December. It is important that we receive input from them by early January to remain on schedule.

\subsection{Survey of Industr1al Equipment Capabilities}

M. Siman-Tov and W. R. Williams

As a part of the ORNL Coal Technology Program, there is a need to conduct a survey of the capability of industry to provide the equipment required for future demonstration and commercial coal conversion plants. 
Part of this project deals with rotary equipment: compressors, turbines, expanders, and pumps. During November, a detailed work schedule for the project was established. Detailed equipment requirement lists are being prepared from Synthoil, Coalcon, HYGAS, and Bi-Gas reports. Requirements for compressors include the following extremes: flow rates up to $1.5 \mathrm{MM}$ scfm and $136 \mathrm{M} \mathrm{acfm}$, temperatures up to $700^{\circ} \mathrm{F}$, inlet pressures up to 3970 psia and outlet pressures up to 4270 psia, and molecular weights ranging from 2.4 to 44.1 . Pump requirements are presently being investigated. Next, turbine and expander requirements will be reviewed. Also during December, letters and standard forms for requesting information will be prepared for mailing to industry in January.

\section{4 Large Air Separation Plant Etudy}

W. R. Gambill

The primary objectives of this study are to determine if significant economies of scale would be provided by building single-train cryogenic air separation plants with capacities in the range of 2000 to 20,000 TPD oxygen production. The oxygen purity is to be $95 \%$ or higher; and the delivery pressure, within the range 1 to $70 \mathrm{~atm}$. abs., is to be determined by economics.

Initial contacts were made with three of the largest U.S. companies involved in $0_{2}$ production: Linde Division of UCC, Air Products and Chemicals, and Airco.

Each of the three appears interested to some degree in this study. A letter summarizing the requirements will be sent to each company. 


\section{PROCESS AND PROGRAM ASSISTANCE}

J. R. McWherter

Process and program analysis studies are being conducted for the ERDA Fossil Energy Office of Program Planning and Analysis. This effort includes research studies on most of the coal conversion and utilization processes. The program objective is to provide, on a consistent basis, technical and economic evaluations of competing processes and systems for coal conversion and utilization.

\subsection{Low-Btu Coal Gasification}

J. P. Belk, H. F. Hartman, and D. E. Reagan

Brief summaries of processes were reviewed to determine which should be selected for more detailed study. This review will continue until the selection procedure is established and certain processes are chosen for the technical and economic evaluations. Work began to determine the type of technical and economic data that should be included in the detailed process descriptions. An example will be prepared and used as a prototype for all processes. Comments were provided on related coal conversion studies and programs. Discussions occurred with personnel involved in beneficiation and gas clean-up studies about the selection of systems that are compatible with low-Btu gasification processes. Material was prepared for a November 19 briefing on: (1) the activities and plans for the low-Btu coal gasification study, and (2) its relationship with other on-going coal conversion studies.

\subsection{Direct Combustion}

H. I. Bowers, E. C. Fox, and R. L. Sinard

This month was spent developing background information in direct coal combustion, and an idea of the R\&D programs that are being conducted in this area. Several contacts were made within ERDA to determine the scope of their programs. TVA was also contacted to discuss the research they are doing in flue gas desulfurization and atmospheric fluidized bed combustion.

On November 24, we transmitted to ERDA and FEA preliminary results from the power plant reliability study. These included nearly all of the analysis of the FEA data base requested initially. We will next attempt other kinds of statistical analyses of the FEA data base. 


\subsection{Advanced Power Conversion Systems}

A. P. Fraas, * G. Samuels, M. E. Lackey, W. M. Wells, and S. Thompson*

The purpose of this study is to examine the relative advantages and disadvantages of the various advanced power conversion systems being considered by ERDA-FE. The prime emphasis is on the technological aspects of the concepts, especially experimental experience in the development of the critical components essential to the technical or economic feasibility of the concept. The assumptions made in the previous studies of performance potential are being examined, the degree of difficulty in developing key components of the systems is being appraised, and the consequences of failure to attain the operating parameters used in the studies will be evaluated.

In order to conduct these studies, background information is being compiled on the performance of existing systems, the rate of development of key components such as compressors and turbines over the past several decades, and, where possible, a summary of past R\&D expenditures on key components. This type of background information should be helpful in appraising the probable cost and success of future programs.

The information gathered in the course of the effort will be organized in a set of topical reports, one for each of the types of power conversion system considered. The first section of each report will give a short history of the R\&D effort including as good a set of data as can be obtained on the R\&D costs. The second section of the report will outline the principal problem areas together with the figures of merit indicative of progress toward solution of the vital problems. The third major section will trace the progress of the $R \& D$ work through the years, mainly by plotting values for the principal figures of merit as obtained in the most promising experiments as a function of the year of the experiment over the past 20 to 50 years. The last section will summarize the performance projected for the system as given by the ECAS and other studies. The latter will include work sponsored by EPRI and the FPC as well as specific systems proposed by various organizations advocating one system or another. The latter will include organizations such as AVCO, G. E., G.A., BCURA, Stal Lavel, Siemens, etc.

A summary report based un the above toplcal reports will compare the developmental progress and the projected full-scale plant performance for the various systems. The expected improvement in component and system performance and costs implied by the record of the past progress for each system will be compared with that required to give a commercially attractive plant. A similar extrapolation of $\mathrm{K} \& \mathrm{D}$ costs will be made for each case. The results will be summarized in a large table to facilitate comparisons between the various systems.

\footnotetext{
*onsultant.
} 
The systems included in the study and the current status of the effort may be summarized as follows:

Fraction of Work Completed

\begin{tabular}{|c|c|c|}
\hline $\begin{array}{l}\text { Technical } \\
\text { history }\end{array}$ & $\begin{array}{c}\text { Development } \\
\text { costs } \\
\end{array}$ & $\begin{array}{l}\text { Topical } \\
\text { report }\end{array}$ \\
\hline 0.7 & 0.1 & \\
\hline 0.9 & 0.6 & Draft by Dec. 1976 \\
\hline 0.5 & 0.1 & \\
\hline 0.5 & 0.1 & \\
\hline 0.3 & 0.1 & \\
\hline 0.9 & 0.8 & Draft by Dec. 1976 \\
\hline 0.9 & 0.1 & \\
\hline 0.9 & 0.2 & \\
\hline 1.0 & 1.0 & Draft completed \\
\hline 0.7 & 0.2 & \\
\hline 0.5 & 0.5 & \\
\hline 0.3 & 0.2 & \\
\hline
\end{tabular}

\subsection{Liquefaction and High-Btu Gas}

Subcontracts for these subprograms are being negotiated.

\subsection{In Situ Coal Gasification}

W. C. Ulrich

The survey of literature pertaining to in situ coal gasification processes and concepts continued. Visits were made to the Laramie Energy Research Center and to Lawrence Livermore Laboratory to discuss in situ gasification projects, with members of the staffs of these two organizations.

A preliminary outline of an evaluation technique for determining the relative states of development of in situ coal gasification processes was prepared. This outline was presented for discussion with representatives of OPPA and the In Situ Coal Gasification Branch in Washington on November $23,1976$. 


\subsection{Beneficiation}

\section{G. R. Peterson and Suman Singh}

A meeting was held with the Project Manager in Washington to establish some of the premises for the study. It was agreed that the beneficiation studies should be developed for plants capable of producing 1500 TPD and 15,000 'IPD of product coal. Certain other premises for the study have also been established.

Process designs have been completed for the above sized coal beneficiation plants for the TRW process applied to one of the list of selected coals. Economic evaluations are currently being performed.

Detailed flowsheets have been completed for the mechanical beneficiation of the 1500-TPD and 15,000-TPD (MAF) capacity facilities for cleaning Pennsylvania, Illinois, and Western Kentucky type coals. Two levels of cleaning processes have been developed for each capacity cleaning plant which are a "mild cleaning" and a "deep cleaning." Material and thermal balances have been completed for each of the systems. Equipment lists are completed for the types of 1500-TPD capacity plant and equipment lists started for the 15,000-TPD capacity plants. Capital and operating costs are completed for the 1500-TPD cleaning plants.

\subsection{Gas Cleanup \\ M. S. Edwards}

Visits were made jointly with the invectigator of in aitu gasification to Laramie Energy Research Center and Lawrence Livermore Laboratory. Primary emphasis of the visits relating to gas cleanups was discussion of commercialization problems in the above-ground testing facility associated with underground gasification of coal. Such questions must be addressed in the evaluation of in situ gasification.

The compilation of possible gas cleanup systems is essentially complete. Current efforts are directed toward setting out guidelines for the selection of a specific process in a specific application. Categorizing of the processes, with generic evaluation of their applications, is underway to permit initial screening of the field to eliminate technically infeasible alternatives. 


\subsection{Coal Prices and Volumes}

O. L. Culberson ${ }^{*}$ and H. F. Soard

Distances from mine to destination have been estimated for about $90 \%$ of the 168 coal contracts which will be used to correlate the minemouth price of Eastern coals to contract quantity, higher heating value, and sulfur and ash contents. Values of these parameters also have been recorded for 108 June contracts for Western coals. When all mileage estimates have been completed, multiple regression analysis of the data will begin; the computer program for this is available.

\subsection{Energy Transportation Costs}

O. L. Culberson *

Estimates of the costs of transporting coal by rail were completed in October, but no progress has been made on the costs of transporting low-Btu and high-Btu gases. Effort was focused on the task for estimating the costs of coals.

\footnotetext{
* Consultant from the University of Tennessee.
} 


\title{
8. FOSSIL ENERGY ENVIRONMENTAL PROJECT
}

\author{
C. R. Boston
}

Since environmental assessments will be done for all advanced fossil energy conversion technologies and all major facilities, the project name has been changed to reflect this broader scope.

In the new FE organization (ERDA Announcement No. 157, November 4. 1976) this project continues to report to the same division which underwent a name change from Fossil Demonstration Plants (FDP) to Major Facility Project Management (MFPM). Because of this reorganization, our sponsors (Initial Operations) within MFPM requested an extremely detailed program plan. An intensive effort was put forth by several team members to provide this document.

Our first major deliverable, "Environmental Inclusions in Requests for Proposals," was also put on an urgent request basis by ERDA and involved a large team effort during the month. An acceptable draft was completed and will be circulated within ERDA for comments.

Progress on the information assessment relative to landfill disposal of solid wastes from coal conversion was slowed because of the two urgent requests mentioned above. The delivery date for this document has been slipped one month to February 28, 1976. 1976.

A program review was presented to our ERDA sponsors on November 9 , 


\section{COAL-FUELED MIUS}

R. S. Holcomb and W. R. Mixon

This profect for analysis, design, and demonstration of a concept utilizing a fluidized-bed coal combustion system as a heat source for a gas turbine generator suitable for applications in Modular Integrated Utility Systems (MIUS) is carried out under the ORNL-HUD-MIUS Program within the Energy Division. Work is supported by the U.S. Department of Housing and Urban Development under HUD Interagency Agreement No. IAA-H-40-72 and by the Energy Research and Development Administration, Office of Fossil Energy (formerly Office of Coal Research, Department of the Interior), under ERDA Contract No. E(49-18)-1742. The project consists of four phases: I - Conceptual Preliminary Evaluation; II - Conceptual Design; III - Detailed Design and Construction; and IV - Shakedown, Performance, and Endurance Tests.

\subsection{Program Review Status}

Project review by ERDA/Fossil Energy continued with respect to future funding and possible redirection of the program. All the detailed design work has been temporarily halted because of uncertainties related to furnace design and use of the gas turbine. This has been done to conserve present funds and insure that further design effort will contribute directly to accomplishment of program objectives. The coal and limestone feed systems and cold flow model tests are applicable to any furnace design and these will be continued until they are completed. The supplemental studies will be continued through their completion.

\subsection{Coal Metering and Feed Systems}

Tnstallation of the coal feed system in the endurance test facility was completed and operation was initiated. Thus far, the system is being run only during the working day and is shut down overnight. After additional experience has been gained with the system, it will be placed on continuous operation for the $1000 \mathrm{hr}$ endurance test.

\subsection{Supplemental Studies}

The $500 \mathrm{hr}$ corrosion test in the FluiDyne furnace was completed on November 15. The test specimens were removed and shipped to ORNL where they will be examined. Fluidyne is preparing a test redort which thev plan to complete in December.

Writing of the heat transfer report has almost been completed. 


\title{
10. ANALYTICAL CHEMISTRY
}

\author{
W. R. Laing
}

\subsection{Sephadex Class Separations}

A. R. Jones

The procedures using Sephadex LH-20 gel which have been developed for the macrofractionation of complex organic mixtures have been applied to COED Syncrude - a product of the hydrogenolysis of coal.

An aliquot of $199.5 \mathrm{~g}$ of material labeled FMC-CRD-12130 (7) Syncrude $\mathrm{T} 460 \mathrm{C}$ was evaporated on a rotary evaporator at $50 \% / 50 \mathrm{~min}$. It lost weight steadily, asymptotically approaching $\sim 179 \mathrm{~g}$. At a weight of $179.8 \mathrm{~g}$ the rate of loss was less than $0.3 \mathrm{~g} / \mathrm{hr}$, so this material was filtered through a 4- to 5.5- $\mu$ glass frit and stored in the dark. Only a trace of insoluble solid remained on the filter.

An aliquot of the filtered, nonvolatile Syncrude weighing $17.14 \mathrm{~g}$ was partitioned on an LH-20 column between $85 \%$ methanol and hexane. The lipophilic fraction weighed $16.61 \mathrm{~g}(96.9 \%)$; the hydrophilic fraction weighed $0.350 \mathrm{~g}(2.0 \%)$. Total recovery was $16.96 \mathrm{~g}(98.9 \%)$. A duplicate run on $101.8 \mathrm{~g}$ yielded $98.3 \mathrm{~g}(96.6 \%)$ lipophilic and $3.39 \mathrm{~g}(3.3 \%)$ hydrophilic. Total recovery was $101.7 \mathrm{~g}(99.9 \%)$.

A $4.089 \mathrm{~g}$ aliquot of the lipophilic fraction was separated on a THF/LH-20 column into $0.049 \mathrm{~g}(1.2 \%)$ polymeric, $3.794 \mathrm{~g}(92.8 \%)$ "sieved" and $0.222 \mathrm{~g}$ $(5.5 \%)$ H-bonding fractions. Total recovery was $4.065 \mathrm{~g}(99.4 \%)$. Eight aliquots totaling $32.422 \mathrm{~g}$ of lipophilic fraction was separated in this fashion with comparable results. The first and last fraction were rechromatographed and the final fractionation results were: polymeric $0.4 \%$, "sieved" $93.2 \%$, and $\mathrm{H}$-bonding $7.7 \%$.

The "sieved" fraction was separated on an isopropanol/LH-20 column into aliphatic, 1- to 2-ring aromatic and polynuclear aromatic compounds. A $3.730 \mathrm{~g}$ aliquot yielded respectively $0.849 \mathrm{~g}(22.8 \%) .2 .577 \mathrm{~g}(69.1 \%)$, and $0.207 \mathrm{~g}(5.6 \%)$ of these materials. Total recovery was $3.633 \mathrm{~g}(97.5 \%)$. A duplicate run showed reproducibility of about $1 \%$.

In summary, the filtered, nonvolatile syncrude was separated into $3.1 \%$ hydrophilic, $0.4 \%$ polymeric, $7.4 \% \mathrm{H}$-bonding, $20.2 \%$ aliphatic, nonpolar, $60.8 \% 1$ - and 2-ring nonpolar aromatic and $4.8 \%$ nonpolar, polynuclear aromatic fractions. 
11. CHEMICAL RESEARCH

L. M. Ferris

This work is reported quarterly.

\section{LIFE SCIENCES}

C. W. Gehrs

This work is reported quarterly. 
THIS PAGE

WAS INTENTIONALLY

LEFT BLANK 


\section{INTERNAL DISTRIBUTION}

1. R. G. Affel

2. S. I. Auerbach

3. M. Bender

4. N. E. Bolton

5. C. R. Boston

6. R. E. Brooksbank

7. C. H. Brown

8. D. A. Canonico

9. J. A. Carter

10. B. R. Clark

11. H. D. Cochran, Jr.

12. E. Copenhaver

13. F. L. Culler

14. R. M. Davis

15. D. G. Doherty

16. M. S. Edwards

17. F. J. Endelman

18. J. L. Epler

19. G. G. Fee

20. D. E. Ferguson

21. L. M. Ferris

22. R. C. Forrester III

23. A. P. Fraas

24. W. Fulkerson

25. W. R. Gambill,

26. R. B. Gammage

27. D. A. Gardiner

28. C. W. Gehrs

29. J. B. Gibson

30. W. L. Greenstreet

31. M. R. Guerin

32. C. W. Hancher

33. L. A. Harris

34. S. E. Herlues

35. J. R. Hightower

36. S. G. Hildebrand

37. M. R. Hill

38. R. S. Holcomb

39. J. M. Holmes

40. J. K. Huffstetler

41. C. L. Hunt

42. G. R. Jasny, $\mathrm{Y}-12$

43. R. L. Jolley

44. J. E. Jones

45. D. S. Joy

46. 0. L. Keller

47. R. T. King

48. W. R. Laing

49. R. S. Livingst on
50. R. E. MacPherson

51. A. P. Malinauskas

52. G. B. Marrow

53. C. J. McHargue

54. L. E. McNeese

55. J. R. McWherter

56. H. J. Metz

57-59. W. R. Mixon

60. J. E. Mrochek

61. P. Nettesheim

62-67. J. P. Nichols

68. L. C. Oakes

69. G. R. Peterson, $Y-12$

70-71. T. W. Picke1

72. W. W. Pitt

73. H. Postma

74. D. E. Reichle

75. C. R. Richmond

76. B. R. Rodgers

77. M. W. Rosenthal

78.. T. H. Row

79. W. L. Russe11

80. Royes Salmon

81. C. D. Scott

82. D. S. Shriner

83. W. D. Shults

84. C. B. Smith

85. G. P. Smith

86. I. Spiewak

87. R, L. Spore

88. E. G. St. Clair

89. J. B. Storer

90. R. A. Strehlow

91. 0. K. Tallent

92. A. J. Thompson

93. D. B. Trauger

94. W. C. Ulrich

95. P. R. Vanstrum

96. J. S. Watson

97. J. R. Weir

98. P. R. Westmoreland

99. M. K. Wilkinson

100. L. V. Wilson

101. R. G. Wymer

1.02. C. S. Yust

103. Patent office

104. Lab. Records-RC

105-111. Lab. Records

112-1.1.4. Central Research Library

115. Document Reference Section 
EXTERNAL DISTRIBUTION

ERDA, Oak Ridge Operations

116. Research and Technical Support Division

ERDA, Washington

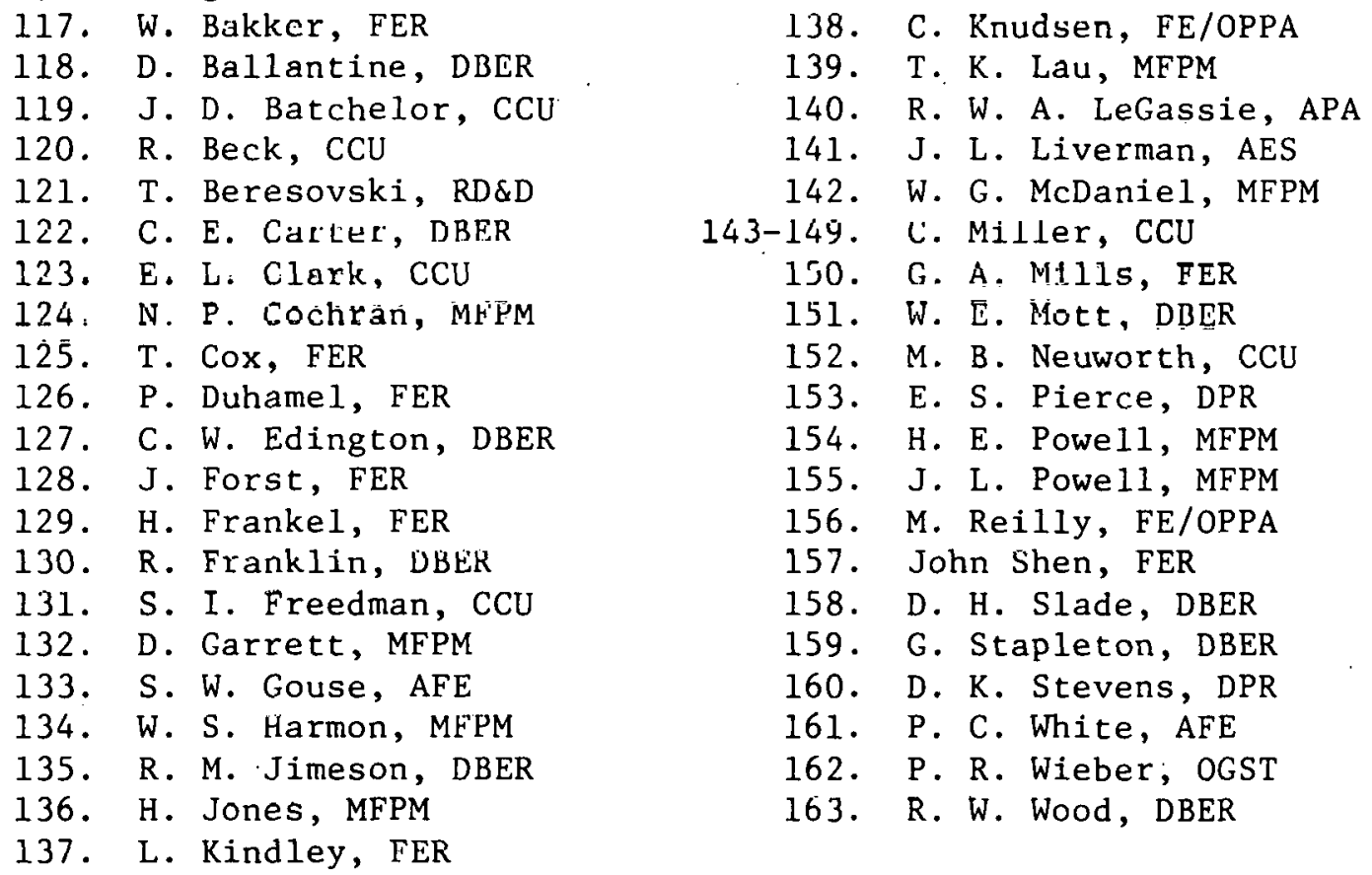

Department of Housing and Urban Development, 45l 7 th Street, S.W., Washington, DC 20410

164. G. S. Leighton

165. J. H. Rothenberg

National Science Foundation, 1800 G Street, N.W., Washington, DC 20550

166. R. S. Guor

167. Robert Rabin

University of Kentucky, Institute for Mining and Materials Research, 213 Bradley Ha1l, Lexington, KY 40506

168. Theresa Wiley, Institute Librarian

169. 0. J. Haun

170. J. K. Shou

171. Robert Rea, Resource Planning Associates, Inc., 44 Brattle St., Cambridge, MA 02138

172. William E. Pepelko, U.S. Environmental Protection Agency, ETRL, 1055 Laidlow, Cincinnati, OH 45237

173. Charles B. Sedman, U.S. Environmental Protection Agency, Research Triangle Park, NC 27711

174. N. S. Boodman, Section Supervisor, U.S. Steel Corporation Applied Research Laboratory, 125 Jamison Lane, Monroeville, PA 15146

175-186. ERDA Pittsburgh Energy Research Center, U.S. Energy Research and Development Administration, Attention: Director for

J. P. Barreca, 4800 Forbes Ave., Pittsburgh, PA 15213 
187-192. The Director, Morgantown Energy Research Center, P.0. Box 800, Morgantown, WV 26506

193. Tetra Tech, Inc., 1911 N. Ft. Myer Drive, Suite 601, Arlington, VA 22209, Attention: Walter McGough, Jr.

194. Cameron Engineers, Attn: Gary L. Baughman, 1315 South Clarkson St., Denver, CO 80210

195-221. Technical Information Center, ERDA 